\title{
ANALYSIS OF GEOTECHNICAL PROPERTIES OF AN EXPANSIVE SOIL MIXED WITH POLYPROPYLENE, SAW DUST ASH AND EGG SHELL POWDER
}

\author{
Irfan Yousuf Wani, Mir Tariq Khurshid \\ PG Student M. Tech Soil Mechanics And Foundation Engineering \\ Sri Sai college of Engineering and Technology, IKGPTU Pathankot Punjab India \\ Er.Neeraj Sharma \\ Asst. Prof.Civil Engineering Department \\ Sri Sai college of Engineering and Technology, IKGPTU Pathankot Punjab India
}

\begin{abstract}
Soil may be defined as all naturally occurring, unconsolidated mineral particles, organic or inorganic in character, lying over the bed rock which is formed by weathering (disintegration)of rocks. The fact that soil may provide all the resistance characteristics necessary for a project illustrates the importance of various methods used to improve soil quality. Most of the failures of soil and earthen dams have been attributed to poor strength. As we know stabilization of soil by adding lime, cement, bitumen etc. are expensive and therefore require an economic replacement. In this thesis work, I have studied about the suitability of Saw Dust Ash, Egg Shell Powder and Polypropylene as a possible additive material to improve the strength of soil. Soil samples were collected and stabilized with Egg Shell Powder in proportions of $1 \%$ to $4 \%$ at $1 \%$ interval by dry weight. The engineering properties were carried out to access the behavior of soil with the addition of eggshell powder. Addition of Egg Shell powder to soil sample lead to increase in unconfined compressive strength. The maximum unconfined compressive strength was attained at 3\% Egg Shell Powder stabilization. Using of chemical admixtures such as lime, cement, bitumen etc. in soil stabilization is highly expensive. Therefore, it is preferable to replace these manufactured materials by other kinds of soil additives to reduce the cost. This research investigates an experimental study of improving engineering properties of soil with Eggshell powder, Polypropylene and Saw dust ash.

The analysis was done by conducting Compaction, and California bearing ratio tests. It was observed that eggshell powder, saw dust ash and polypropylene had significant effect in the engineering properties of the soil. The results showed that the unconfined compression strength and California bearing ratio values had increased with increase in Egg Shell Powder, Saw Dust Ash and Polypropylene
\end{abstract}

content up to certain limit. The aim of the present work is to study the effect of Polypropylene, Saw Dust Ash and Egg Shell Powder on the engineering properties of soil.

Keywords- Egg Shell Powder, Liquid limit, Plastic Limit, Polypropylene and Saw Dust Ash.

\section{INTRODUCTION}

In general soil is defined as the loose surface material overlying solid rocks. So it is understandable that the soil is one of the most ancient construction materials and is most widely used material due to its low cost, wide spread and easy availability. Besides its use in the construction of earthen dams and in road construction, soil is also used for numerous constructions purposes. Soil in its untreated state is low in strength and high in compression. To have the construction as per desired parameters, soil engineers are left with two choices- either replacement of soil or to improve the desired properties of available soil. The main properties of soil needed for the construction are low compressibility and high strength. Soil is the uppermost unconsolidated material of the earth present naturally in the universe. It is formed by the decomposition of rocks under the influence of naturally occurring conditions such as wind, rain, snow, heat, etc. It is abundantly available and is the cheapest construction material. It is a complex material because of its highly variable composition and characteristics. The characteristics of soil change according to topography and its location. For safer construction, the properties of soil should match with the design requirements of an engineering structure. Geotechnical engineer plays an important role in this work for checking whether the requirements of the structure are fulfilled by the soil or not. Construction of engineering structures on poor soil involves a great risk. These soils show settlement, low shear strength and high compressibility. 


\section{MATERIALS}

\section{A. Soil}

Soil being very dynamic in nature, it's properties depend upon several factors such as location, climatic condition of the area, its constituent materials and temperature etc. Very often the available soil is not suitable for construction purposes. Strength, permeability and stability is not as desired by the geotechnical engineers. For studying the engineering behavior of soil, we have to deal with the stability of underground structures, retaining structures, foundations, slopes, earthen dams and pavement construction.

Expansive Soil were used in this research work. Stability of every structure depends on the type and characteristics of foundation which in turn depends on the type of soil. Many problems erupt if expansive soil or natural soil is to be used in foundation, because of its shrinkage and swelling properties. There are many methods to make natural soil stable for various constructions. Natural soil is comfortable for road work, compared to other types of soil. There are two ways to enhance the quality of sub grade soil -"Replacement of soil" or "Soil stabilization".The soil samples were collected from Beerwah which is about $20 \mathrm{~km}$ from Budgam town. Samples for soil were created in the Mount Geotech lab Srinagar. Various preliminary tests for index properties and strength were determined in the lab.

\section{B. Egg Shell Powder}

Eggshells has not been in common use in soil engineering as a stabilizing material and it could be a good replacement for artificially synthesized lime, since its chemical composition is similar to that of lime. Its composition primarily contains calcium, magnesium carbonate (lime) and protein. Egg shells may be of any Oviparous animal. As per ease we have taken chicken egg shells. Chicken eggshell is a waste material from domestic sources such as poultries, hatcheries, homes and fast food joints. The high amount of calcium oxide is associated with the presence of calcium carbonate, which is the main percentage component of eggshell. Thus, the eggshell waste can be considered from the chemical analysis quite similar to calcite calcareous. Egg shells used in this study was collected from one of the famous restaurants in Srinagar J\&K. namely Samcii. The samples were rinsed with water to remove the residue of eating part of egg that is attached on the eggshell, then egg shells are dried under the sunlight.

\section{SAW DUST ASH}

The Saw dust was collected from a local Saw mill 'Ashia Saw Mills' in Industrial area, Rangreth Srinagar Jammu and Kashmir @ Rs 2 per Kg. The saw dust collected was obtained from sawing of teak and deodar wood. Saw dust is actually a by-product of sawmills generated by cutting, grinding, drilling, sanding, sawing or pulverizing wood with a saw or by any other tool. These operations both shatter lignified wood cells and break out whole group of cells. Shattering of wood cells creates dust, while breaking out of whole group of wood cells creates chips.

After collection, Saw dust was cleaned and unwanted impurities like bark and organic content was removed and then it was dried in open atmosphere and burnt. The Saw Dust Ash (SDA) was then sieved through 600 micron sieves to remove the lumps, gravels, unburnt particles and other materials which are detrimental to soil. The Saw Dust Ash passing through 600 microns sieve was used for the laboratory work Saw dust, itself has little cementitious value but in the presence of moisture it reacts chemically and forms cementitious compounds and attributes to the improvement of strength and compressibility characteristics of soils. So in order to achieve improvement in geotechnical properties of soils and also to make use of the industrial wastes, the present experimental study has been taken up.

\section{Polypropylene}

Polypropylene (PP) is a lightweight fiber, it has density of $0.91 \mathrm{gm} / \mathrm{cm}^{3}$. It does not absorb water. It has excellent chemical resistance. PP fibers are very resistant to most of the acids and alkalis. It is also known as polypropene and is used in a wide variety of applications. It is produced via chain growth polymerization from the monomer propylene. Its properties are very similar to polyethylene, but it is slightly harder and more heat resistant. It is a white, mechanically rugged material and has a high chemical resistance. PP is the second most widely produced commodity plastic (after polyethylene) and it is often used in packaging and labeling

\section{EXPERIMENT AND RESULT}

\subsection{Composition of Soil specimen}

Geotechnical engineers classify the soil particle types by performing tests on disturbed (dried, passed through sieves, and remolded) samples of the soil. This provides information about the characteristics of the soil grains themselves. Classification of the types of grains present in a soil does not account for important effects of the structure of the soil.

Table 1 Soil composition

\begin{tabular}{|c|c|c|}
\hline S.No. & Element & Grade \% \\
\hline 1. & Sand & $14.63 \%$ \\
\hline 2. & Silt & $38.18 \%$ \\
\hline 3. & Clay & $47.18 \%$ \\
\hline
\end{tabular}




\begin{tabular}{|c|c|c|}
\hline 4. & Gravel & 0 \\
\hline
\end{tabular}

Table 2 Typical values of OMC, MDD etc of the concerned sample.

\begin{tabular}{|c|c|c|}
\hline S.No. & Properties & Values \\
\hline 1 & OMC & $24 \%$ \\
\hline 2 & MDD & $1.82 \mathrm{gm} / \mathrm{cc}$ \\
\hline 3 & CBR & $2.04 \%$ \\
\hline 4 & UCS & $2.62 \mathrm{~kg} / \mathrm{cm}^{2}$ \\
\hline 5 & Specific Gravity & $2.63 \%$ \\
\hline 6 & Liquid Limit & $48.66 \%$ \\
\hline 7 & Plastic Limit & $27.82 \%$ \\
\hline 8 & Plasticity Index & $21.84 \%$ \\
\hline 9 & $\mathrm{pH}$ & 4.06 \\
\hline
\end{tabular}

3.2 Unconfined Compressive Strength Test

Table 3 UCS Values of Various Mix Proportion At Different Curing Periods

\begin{tabular}{|c|c|c|c|c|}
\hline S.No. & $\begin{array}{c}\text { Mixture \% } \\
\text { Soil: SDA: } \\
\text { ESP: PP }\end{array}$ & $\begin{array}{c}\text { UCS 3 } \\
\text { days } \\
\text { curing } \\
\mathbf{k g} / \mathbf{c m}^{2}\end{array}$ & $\begin{array}{c}\text { UCS 7 } \\
\text { days } \\
\text { curing } \\
\mathbf{k g} / \mathbf{c m}^{2}\end{array}$ & $\begin{array}{c}\text { UCS 28 } \\
\text { days } \\
\text { curing } \\
\mathbf{k g} / \mathbf{c m}^{2}\end{array}$ \\
\hline 1. & $100: 0: 0: 0$ & 0.96 & 0.96 & 0.96 \\
\hline 2. & $93: 5: 1: 1$ & 1.16 & 1.62 & 2.24 \\
\hline 3. & $88: 10: 1: 1$ & 1.39 & 1.83 & 2.64 \\
\hline 4. & $83: 15: 1: 1$ & 1.67 & 2.24 & 2.85 \\
\hline 5. & $78: 20: 1: 1$ & 1.88 & 2.74 & 3.46 \\
\hline 6. & $92: 5: 2: 1$ & 2.33 & 2.85 & 3.56 \\
\hline 7. & $87: 10: 2: 1$ & 2.49 & 3.15 & 3.71 \\
\hline 8 & $82: 15: 2: 1$ & 2.87 & 3.76 & 4.37 \\
\hline 9. & $77: 20: 2: 1$ & 2.96 & 3.93 & 4.68 \\
\hline 10. & $91: 5: 3: 1$ & 3.25 & 4.07 & 5.29 \\
\hline 11 & $86: 10: 3: 1$ & 3.31 & 4.38 & 5.50 \\
\hline $\mathbf{1 2 .}$ & $\mathbf{8 1 : 1 5 : 3 : 1}$ & $\mathbf{3 . 5 6}$ & $\mathbf{4 . 8 8}$ & $\mathbf{6 . 7 1}$ \\
\hline 13. & $76: 20: 3: 1$ & 3.36 & 4.17 & 5.98 \\
\hline 14. & $90: 5: 4: 1$ & 3.05 & 3.82 & 5.30 \\
\hline 15. & $85: 10: 4: 1$ & 2.85 & 3.26 & 4.63 \\
\hline & & & & \\
\hline
\end{tabular}

\begin{tabular}{|c|c|c|c|c|}
\hline 16. & $80: 15: 4: 1$ & 2.34 & 2.85 & 3.56 \\
\hline 17. & $75: 20: 4: 1$ & 1.93 & 2.24 & 3.05 \\
\hline
\end{tabular}

The compressive strength of the treated soil is greater than untreated soil. The UCS value of the mix soil specimen increases from $0.96 \mathrm{~kg} / \mathrm{cm}^{2}$ to 6.71 at 28 days curing for $15 \%$ SDA with ESP (3\%), PP (1\%) and Soil (81\%).

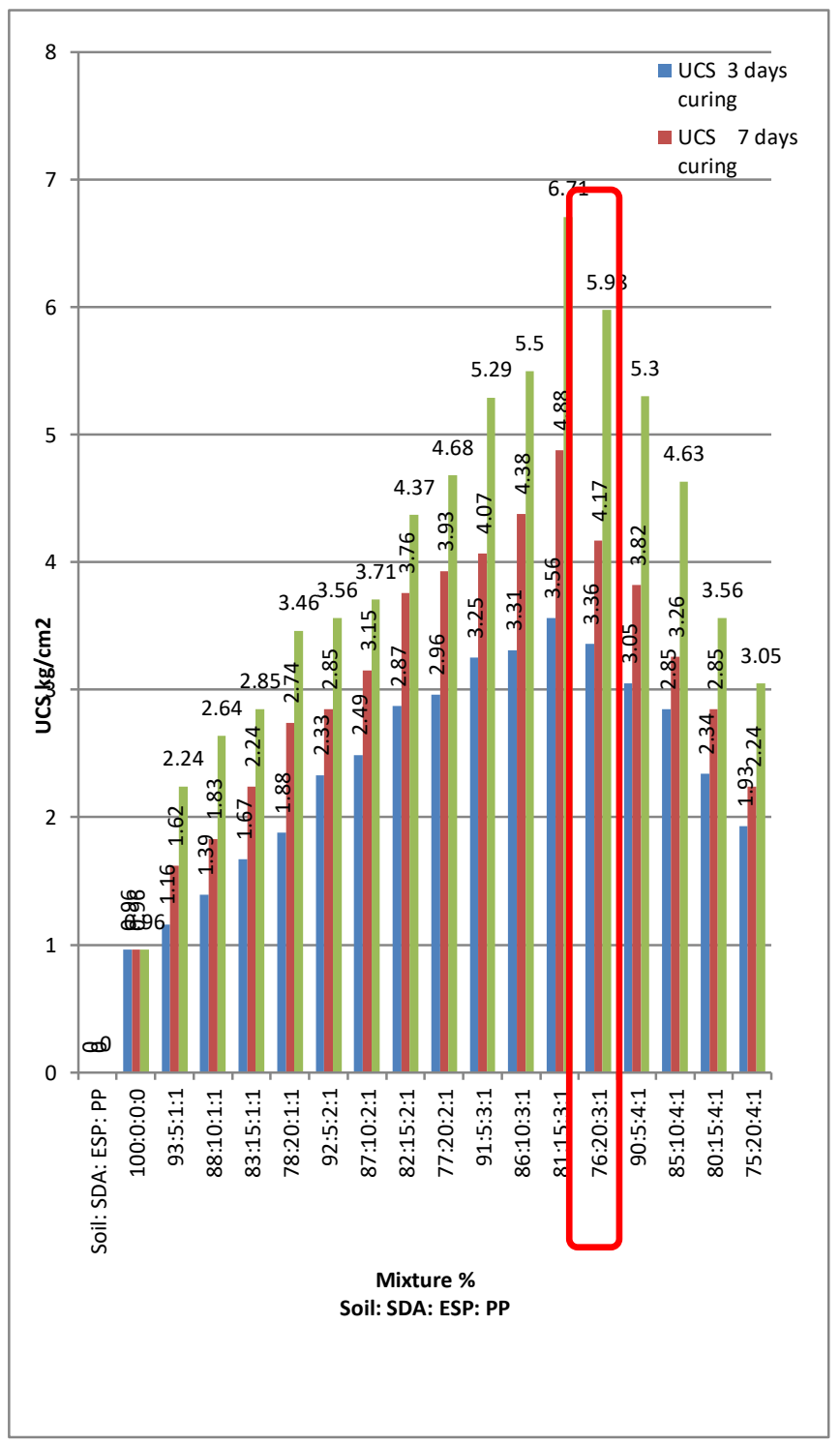

Fig. 1 Variation of Unconfined Compressive Strength due to change in mix proportions. 


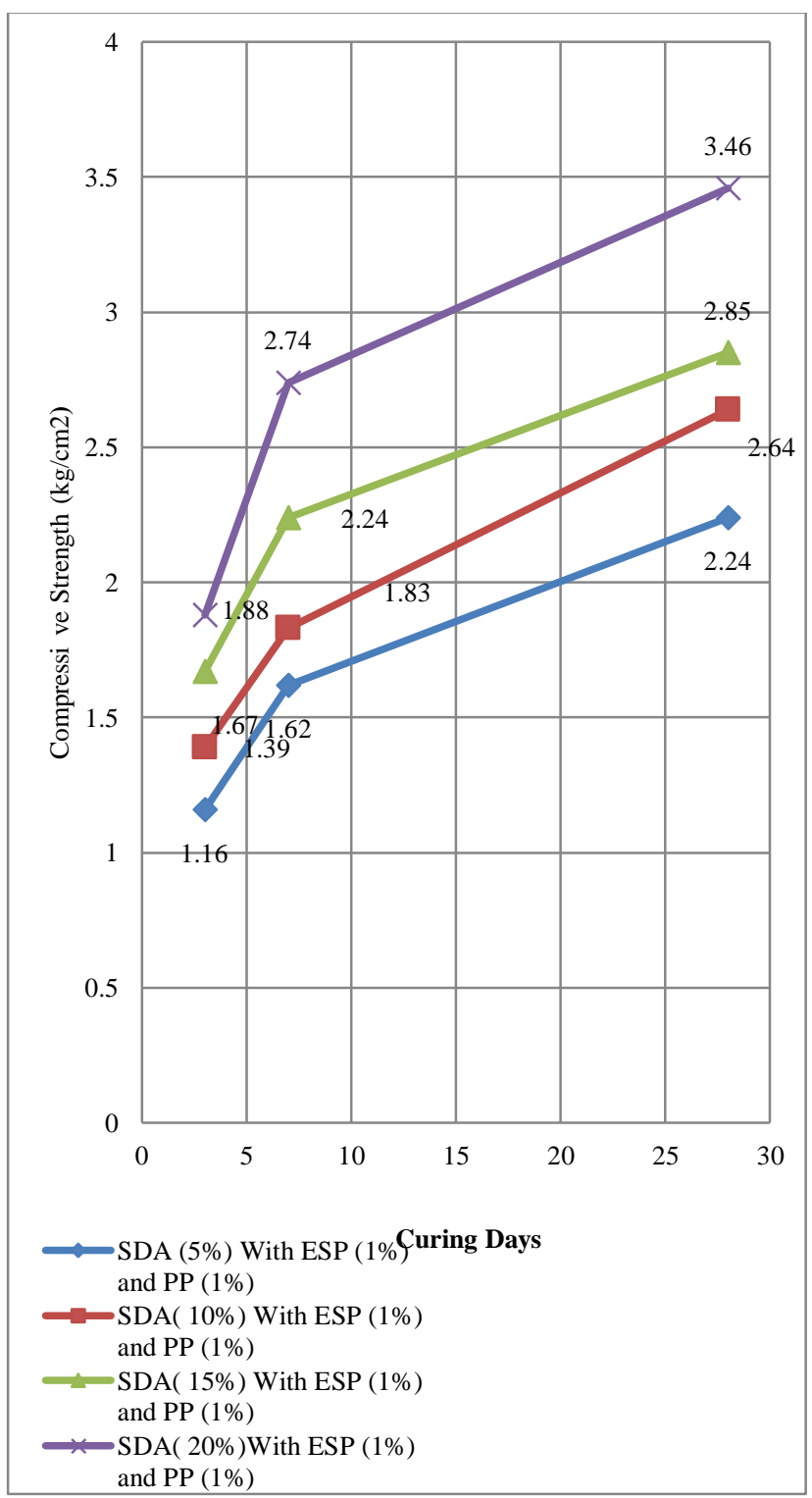

Fig. 2 UCS value at (5\% - $20 \%$ of SDA) with varying combinations of Soil and ESP

Fig.2 shows that unconfined compressive stress of the expansive soil increased with the increase in percentage of Saw Dust Ash in it. UCS increased from $0.96 \mathrm{~kg} / \mathrm{cm}^{2}$ to $3.36 \mathrm{~kg} / \mathrm{cm}^{2}$ on adding SDA from $5 \%$ to $20 \%$ keeping percentage of ESP and PP constant at $1 \%$. The compressive strength increased not only with the addition of percentage of SDA but also it showed an increase in its strength by each passing day.

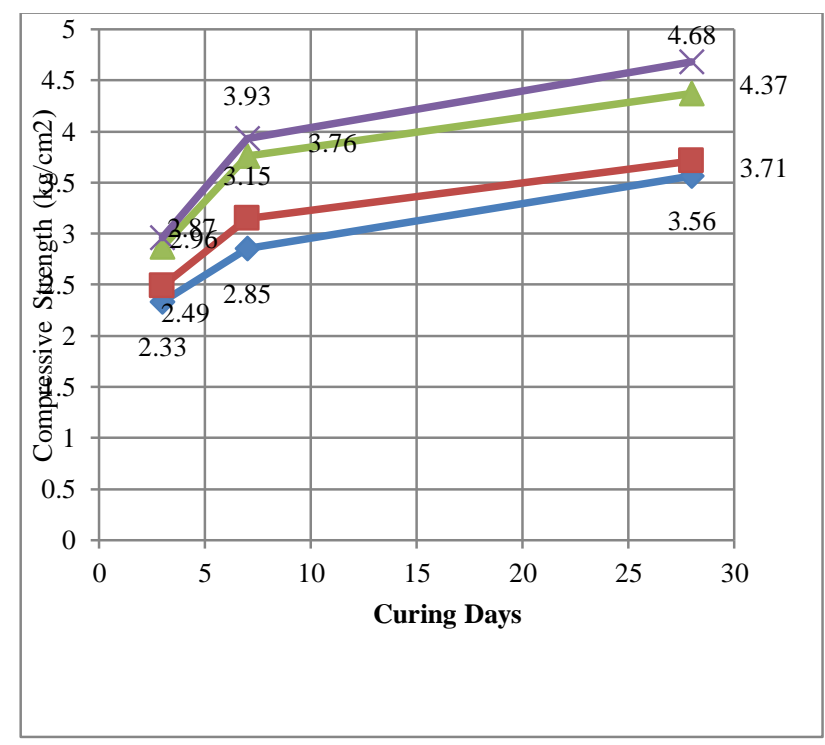

Fig. 3 UCS value at (5\% - 20\% of SDA) with varying combinations of Soil and ESP

Fig. 3shows that UCS of the soil increases with increasing SDA percentage from $5 \%$ to $20 \%$.and ESP (2\%) Keeping PP percentage fixed at one percent.

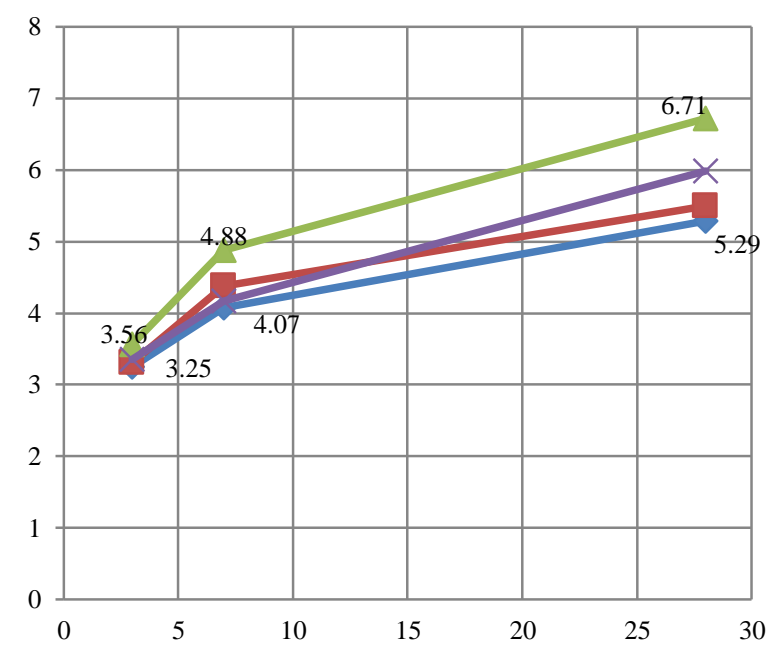

Fig. 4 UCS value at (5\% - $20 \%$ of SDA) with varying combinations of Soil and ESP Fig.. above shows us the unconfined compressive strength of expansive soil increases upon mixing the above discussed additives in a proper proportion. In this arrangement we saw compressive strength reached to its maximum value of 6.71 $\mathrm{kg} / \mathrm{cm}^{2}$ on 28 days of curing by mixing $15 \%$ of SDA along with $3 \%$ ESP and $1 \%$ PP. 
4. California Bearing Ratio Test

Table 4 CBR Values for $2.5 \mathrm{~mm}$ penetration of Various Mix Proportion At Different Curing Periods

\begin{tabular}{|c|c|c|}
\hline S.No. & $\begin{array}{c}\text { Mixture \% } \\
\text { Soil: SDA: ESP: PP }\end{array}$ & CBR ratio(\%) \\
\hline 1. & $100: 0: 0: 0$ & 1.74 \\
\hline 4. & $\mathbf{8 1 : 1 5 : 3 : 1}$ & $\mathbf{2 . 9 8}$ \\
\hline
\end{tabular}

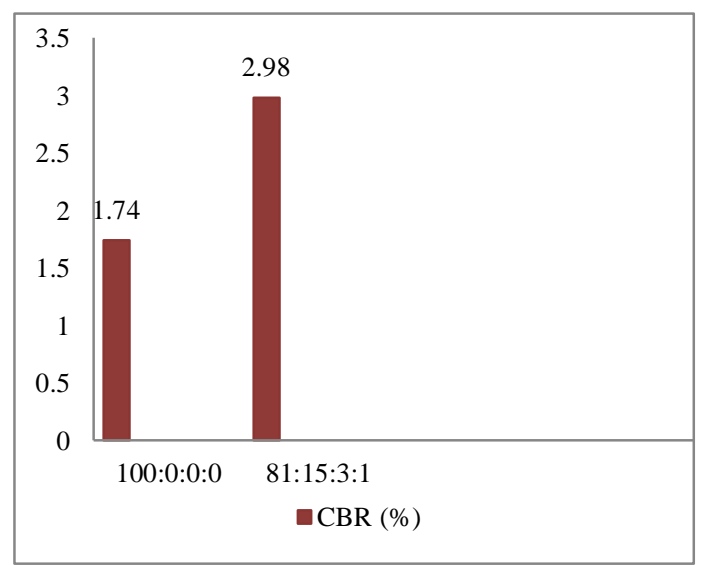

Fig. 5 CBR of untreated and treated Soil.

Bar Diagram shows that the bearing capacity of the soil gets improved by mixing the said additives in a proper fashion. The optimum mix (81:15:3:1) represents that CBR increases from $1.74 \%$ to 5.49

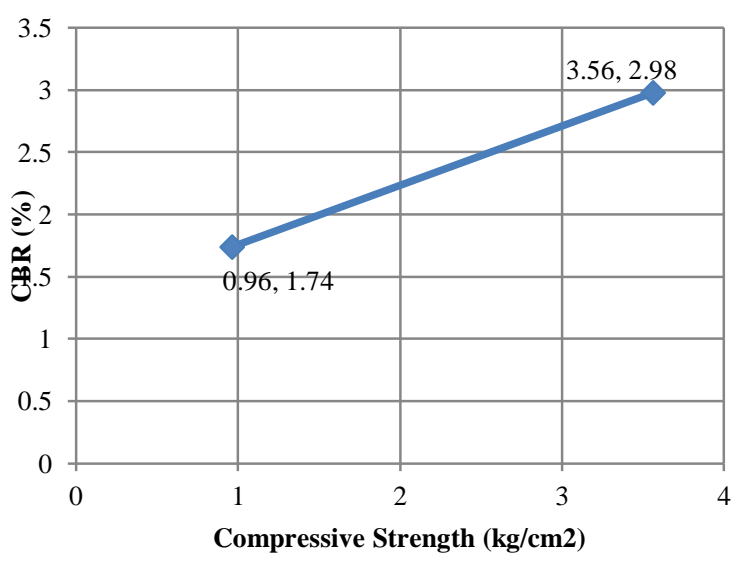

Fig. compressive strength versus CBR of expansive soil at optimum mix.
The graph plotted between CBR and UCS clearly indicates that these are proportional to each other as the compressive strength increases the CBR value also increases.

\section{CONCLUSION}

The physical properties and engineering characteristics of virgin soil were studied, which includes moisture content, compaction characteristics and unconfined compressive strength. The addition of Saw Dust Ash (SDA) improved the properties of the virgin soil, making it good for sub-base material.

The following conclusions were made from this experimental study:-

1. We can utilize the eggshell waste as a useful soil stabilizing material. By using the eggshell powder as a soil stabilizer, we can minimize the waste disposal problem of eggshell.

2. From the experimental results we observed that liquid limit of the soil decreased from $48.66 \%$ to $39.06 \%$ whereas, Plastic limit increased from $27.82 \%$ to $34.04 \%$.

3. The maximum dry density of soil increased from $1.82 \mathrm{gm} / \mathrm{cm}^{3}$ to $2.189 \mathrm{gm} / \mathrm{cm}^{3}$ on adding $15 \% \mathrm{SDA}, 3 \% \mathrm{ESP}$ and $1 \% \mathrm{PP}$.

4 UCS and CBR of the soil showed an improvement at optimum mix $(81: 15: 3: 1)$ from $0.96 \mathrm{~kg} / \mathrm{cm}^{2}$ to $71 \mathrm{~kg} / \mathrm{cm}^{2}$ and $1.74 \%$ to $5.49 \%$ respectively.

Keeping everything in consideration, it can be concluded that fiber reinforced soil can be considered as a good ground improvement technique specially in engineering projects and Egg Shell Powder acts as a cementitious material on weak soils where it can act as a substitute to deep/raft foundations, and makes it economical in all respects.

This study has evaluated the extent to which Saw Dust ash can improve the fundamental geotechnical properties such as consistency, compaction, UCS, shear strength, and settlement characteristics of expansive soil.

\section{REFERENCE}

[1] [Qureshi, Z. N., Raina, Y. M., \& Rufaie, S. M. A. (2016) "Strength Characteristics Analysis of Concrete Reinforced With Lathe Machine Scrap", International Journal of Engineering Research and General Science,4(4), 210-217.

[2] Gray, D.H. \& Ohashi, (1983) "Mechanics of fiber reinforcement in sand", Journal of Geotechnical Engineering, 109(3), 335-353.

[3] Chen, H. \& Wang, Q. (2006). "The behaviour of organic matter in the process of soft soil stabilization using cement", Bulletin of Engineering Geology and the Environment, 65(4),445-448. 
[4] A.O. Ilori and E.A. Udo (2015) "Investigation of geotechnical properties of Lateritic soil with Saw Dust Ash", IOSR Journal of Mechanical and Civil Engineering (IOSR-JMCE Vol. 12, 2015).

[5] Parkar T. W. (1997) "Sawdust cement and sawdust products", Journal of light weight concrete, 1,2 p.p.41,108 Dec. 1997.

[6] K.R. Arora (2008) "Soil Mechanics and Foundation Engineering (Geotechnical Engineering)", Standard Publishers Distributors, Delhi, 2008.

[7] Jain, V.K., Dixit, M. and Chitra, R. (2015) "Correlation of plasticity index and compression index of soil", IJIET., 5(3), June, 263-270.

[8] J. E. Bowles (2012) "Engineering Properties of Soils and their Measurements", $4^{\text {th }}$ edition, McGraw Hill Education (India) Private Limited, New Delhi, 2012.

[9] Roy, S. and Dass, G. (2014) "Statistical models for the prediction of shear strength parameters at Sirsa, India", I. Journal of Civil and Structural Engineering.

[10] IS: 2720 - Part 5, 1970, "Determination of liquid and plastic limits", BIS, New Delhi.

[11] IS: 2720 - Part 6, 1972, "Determination of shrinkage factors", BIS, New Delhi.

[12] K.V.S. Apparao and V.C.S. Rao (1995) "Soil Testing Laboratory Manual and Question Bank", Universal Science Press, New Delhi, 1995.

[13] IS: 2720(Part 2), 1973 "Methods of Test for Soils, Determination of water content",

[14] Terzaghi, K., Peck, R.B., and Mesri, G. (1996) "Soil Mechanics in Engineering Practice", Third Edition, John Wiley \& Sons, Inc. Article 18, page 135.

[15] Punmia B.C. (2007), "Soil Mechanics \& Foundations", Laxmi Publications. 